\title{
IMAGE OF WOMEN IN GADIS KRETEK NOVEL BY RATIH KUMALA BASED ON FEMINISM PERSPECTIVE
}

\author{
Suhendra $^{a)}$, Tri Mahajani ${ }^{a)}$, Aam Nurjaman $^{a)}$, Stella Talitha $^{\left.a^{*}\right)}$, Ruyatul Hilal M. ${ }^{a)}$, Tania Lestari ${ }^{a)}$ \\ ${ }^{a)}$ Universitas Pakuan, Bogor, Indonesia \\ ${ }^{*}$ Corresponding Author: stella.talitha@unpak.ac.id
}

Article history: received 09 January 2021; revised 13 February 2021; accepted 26 February 2021

\begin{abstract}
Novel is part of a literary work that contains a series of life stories of characters and people around them. The portrayal of character is described by an arranged series of events, setting, and furrows. It aims to examine a women's image in the feminism perspective of a Gadis Kretek novel. The feminism perspective in the writing is focused on the image of women embracing the physical image of a woman's physical transformation. Psychic image, linked to the ability of women to think, to aspire, and to feel. Image in the family, concerning the roles of women in the family. Image in society can be demonstrated by the female role in society embodied in behavior. This research used a qualitative descriptive method with library study techniques. The conclusion of this study shows that the image of female physis is more characterized by the physical depiction of the main character from aspects of age, maturity, and behavior like adults. Psychic imagery is depicted through the permmature of thinking in a mature figure. The image in the family appears to be attached to the main character who plays a child. The image in society is characterized by the role of the main character portrayed as an intelligent, independent, responsible, and cheerful woman.
\end{abstract}

Keywords: feminism; women's image

\section{INTRODUCTION}

Literary work is a medium for the author to express ideas, ideas, and feelings to be conveyed about the meaning and nature of life, whether experienced and witnessed by the author himself or heard from the stories of others. A literary work can be conveyed orally as well as in writing, an oral literary work is a literary work that is pronounced in the form of bedtime stories or readings during traditional ceremonies. Meanwhile, literary works of writing are in the form of novels, poetry and drama scripts. Novels are literary works known to be close to life.

In a novel literary work, there are constructive elements, namely intrinsic and extrinsic elements. Figures in literary works cannot be separated from men and women. Discussions about women are always hot to talk about. Women are often seen as weak and helpless, second to men. The image of women formed in society is culturally engineered. Passive, submissive, inferior, and irrational images of women are often mentioned in literary works. Stereotypes of women as loyal and devoted wives and mothers, gentle women, dominant women, and so on are not uncommon to be found in literary works.

The novel is a prose composition that is included in modern literature. Novel as a work of fiction offers a world that contains an idealized model of life, an imaginative world, which is built through various intrinsic elements such as events, plots, characters and characterizations, settings, points of view, etc., all of which are also imaginative [1]. A novel is a story with a long plot about one or more books that work on the imaginative lives of men and women. It can be concluded that the novel is a prose essay that deals with the problems of human life or the author's observations of the existing reality and is accompanied by intrinsic and extrinsic elements.

The concept of feminism is to reverse the paradigm that women are under the domination of men, women are complementary, and women are secondary beings [2]. Meanwhile, etymologically feminism comes from the word femme (women) which means women (single) who struggle to fight for the rights of women (plural) as a social class [3]. Feminism is an attempt to end the oppression and exploitation of women. The goal in feminism is not just a gender issue, but a "humanitarian" issue or fighting for human rights. The feminist movement is a struggle in order to transform unjust social systems and structures into justice for you men and women.

Female image consists of the word image and woman. Image means a way of forming a personal mental image or image of something; a visual impression or image created by a word, phrase or sentence, and is a unique basic element in prose and poetry works. Images are images of wishful thinking or thoughts, while every thought image is called an image or image [4].

Women are imaged as individual beings, with physical and psychological aspects and as social beings with family and community aspects. These aspects are detailed on the basis of the thought image against them. This thought image is manifested by the support of other types of images such as visual images, hearing, motion, etc. as already mentioned. Self-Image of Women in Physical Aspects Physiologically, adult women are characterized by physical signs. These physical signs include experiencing 
menstruation and other physical changes, such as the growth of hair on certain parts of the body, changes in voice, and so on. Girls at a certain age also make various decisions because of their secondary characteristics as physical characteristics [4]. Depending on what the provisions of the woman are, she has to decide what to do because she is having a menstrual cycle, or because her breasts are getting bigger.

The physical signs that lead girls to become women today also influence the behavior that is considered appropriate for them as adult women. With regard to secondary characteristics, women also have to make decisions that cannot be separated from their desires as adult women and which are deemed appropriate for them. Psychological aspects of women are different from men as stated in psychology. The difference between male and female psychics lies in the characteristics of the secondaryity of emotionality, and the activity of mental functions; in women, the function of secundity lies not in the intellect, but in feelings [4]. This feeling is a characteristic that marks his psychic image. It has been said before that from the physical and psychological aspects, there is a difference between men and women. It also affects his image in the family. Women are imaged as naturally living in a household environment. Her job as a mother and educator for her children is one that nature gives to women. Therefore, the image of women in the family is considered a natural social image.

Social attitudes are expressed based on the evaluative process in individuals. Therefore, the value of the stimulus in the form of good or bad, positive or negative, pleasant or unpleasant, like it or not, which then crystallizes as a potential reaction to the object of attitude. The image of a woman is a mental picture of her spirituality and daily behavior that can only be expressed by women in various aspects. The aspects that can be seen from the image of women are the self-image of women which consists of physical images and psychological and social image of women consisting of images of women in the family and society.

\section{RESEARCH METHODS}

The research method used in this research is a qualitative method. Qualitative research methods are research methods based on the philosophy of postpositivism. The research method used is descriptive qualitative method with literature study techniques [6]. The research is in the form of data in the form of quotes, sentences and paragraphs showing the image of women in the novel Gadis Kretek by Ratih Kumala. The image of women consists of self-image and social image of a socialization process which is manifested in individual social attitudes through their words or behavior. So individual social attitudes are an important scheme in human life [4]. individual attitudes with social attitudes put the main emphasis on social attitudes and human socialization. The end product of a woman. Self-image consists of aspects of physical image (CF) and psychological image (CP), while social image consists of aspects of images in the family (CK) and images in society (CM). The data source in this research is the novel Gadis Kretek by Ratih Kumala [5].

The literature study technique is used by researchers as a basis for theoretical studies that contain information with the help of books in the library, literature, notes, and reports related to the focus of the problem to be solved. In addition, researchers read the novel Gadis Kretek thoroughly, and used computers and writing tools to obtain data to be analyzed. Qualitative descriptive analysis technique is a technique used to collect existing data first then classified and then analyzed. Furthermore, it is interpreted so that it can provide an objective picture of the research.

\section{RESULTS AND DISCUSSION}

\section{Physical Image Analysis}

(1) I imagined what Jeng Yah would look like. Does he have tall hair with hairspray? Is she wearing a wide skirt that makes her want to keep circling until it fluffs up? Jeng Yah impressed him so much, that even in his dark days the name Jeng Yah was mentioned [5]. In the quote from the novel Gadis Kretek above, there is an image of a woman in the form of a physical aspect. This can be seen in the part of the sentence "I imagined what Jeng Yah's face would look like. Does he have tall hair with hairspray? Is she wearing a wide skirt that makes her want to keep circling until it fluffs up?". This part of the sentence shows the physical image of a woman, namely Jeng Yah, which is marked by the age of Jeng Yah who has entered his mature or adult age. One of the manifestations of the physical image of women is the physical characteristics of adult women as indicated by physical signs as well as behaviors that are considered appropriate for adult women. Judging from the assumption of Lebas as the character who conveyed the sentence, Jeng Yah has entered the proper age to care for himself like most other women in the 1960s who were synonymous with upward hairstyle. In addition, the explanation in the next sentence regarding the skirt that flares on part of the sentence "Is she wearing a wide skirt that makes her want to always spin around until it fluffs up?" create a self-image of Jeng Yah in the physical aspect as a feminine female figure. At the age of Jeng Yah being a girl and having a relationship with Romo, as said by Lebas in the next sentence, "Jeng Yah is as memorable and memorable for Romo" indicates that Jeng Yah occupies a position in Father's heart because of his beautiful beauty. Lebas' questions that he asked in his heart succeeded in making him wonder how important Jeng Yah was to the life of Romo, so that at the end of his life, who could only lie there, Father still worried about the name Jeng Yah.

Psychic Image Analysis (9) "Why don't you take care of free kretek! Only? Harvested. " Dasiyah, her daughter who this year will enter the age of 17, one day asked Idroes Moeria. "Independent! I already have a market. Stay on the edge" [5]. In this quote, there is an image of a woman in the 
psychological image aspect. This can be seen clearly in the sentence "Why don't you take care of free kretek! Only? Cultivated. ". It has been mentioned that one of the psychological aspects of a woman can be seen from her ability to think. In this quote, Dasiyah's ability to think well has shown that the business that had been done by his father was better continued than having to issue new kretek products whose profits in the market were unclear. This explanation is supported in the next sentence, namely. "Independent! I already have a market. Stay on the edge. ". As someone who has been in the kretek world for a long time since she was little, Dasiyah is able to weigh the advantages and disadvantages that will be received if her father insists on continuing her wish. At a mature age as a girl, Dasiyah has learned a lot about kretek and Ayanyanya's business trips. He did not want anything bad to happen to Idroes Moeria's kretek business.

\section{Image Analysis in the Family}

(4) Dasiyah often pays attention to her father's rituals. Then, he collected kretek saris in the afternoon. Not reluctant, he also asked Rukayah to also collect the kretek juice stuck to his palm. He left it all to his father [5]. The data above is included in a form of female image, namely the image in the family. This is because Dasiyah did her role well as a child. The image of women in the family cannot be separated from their roles as wives, mothers, or family members. Dasiyah has shown himself to be a child of Idroes Moeria in the words "Dasiyah often pays attention to his father's rituals." then continued with the sentence "He left it all to his father.".

Dasiyah intended to please her father with kretek which she managed to make using her own hands. In addition, the image of Dasiyah in the family is also reflected as a Mbakyu or Big Brother. Dasiyah did not hesitate to ask Rukayah to help her please their father. This is shown by the sentence "He did not hesitate, he also asked Rukayah to also collect the kretek juice stuck to his palm". Without taking the slightest advantage, Dasiyah handed over their kretek to her father followed by Rukayah's explanation of helping her. Dasiyah has portrayed the image of a good brother.

\section{Image Analysis in Society}

(3) When Dasiyah was 10 years old, the little girl was already skilled at rolling kretek. Since he was able to walk and made the pelingting worried that the little boy would fall because he was not balanced yet [5]. The quote shows the social image of women in the image aspect in society. This is shown in the sentence "Sejak ia bisa jalan dan membuat para pelingting khawatir anak kecil itu terjatuh karena belum seimbang". It has been explained that women's social attitudes will show a woman's social image, besides that if a woman receives a good stimulus from her environment, the final product of women's attitudes will also be good. Dasiyah has received a good stimulus so that the final product of her is Dasiyah's social attitude which can be seen in her speech and behavior. Since she was a child, Dasiyah has been hanging out with rollers, no wonder the sentence
"When Dasiyah was 10 years old, this little girl was already good at rolling kretek." This was solely done not because Dasiyah was the son of the rollers boss, but because Dasiyah liked to do rolling activities with the rollers who worked in her father's factory. Not surprisingly, until Dasiyah was a teenager, she was able to get to know her workers well, as is further explained in the novel.

\section{CONCLUSION}

The physical image of women is often used as the basic basis for differentiating between men and women. Whereas with a woman's physique, women can also do activities that are no less innovative and creative than men. Psychic image of a woman, the psychological image of women lies in the secondaryity of emotionality, where women's feelings are more dominant than their intellectual abilities. However, that does not mean that women cannot balance the ability to feel and think. Women can do business, trade, and many other activities that a woman can do, such as the main female character in the novel, Jeng Yah. Of course, women occupy all roles in life.

The image of a woman's family can be found with the role of women in the family that can be found as wives, mothers, or family members. In Gadis Kretek novel, the role of the main female character is as a child and also an older brother. Women are part of society, basically women also need help from others.

The image of women in society is a product that is manifested in individual social attitudes through words and behavior. If a woman is positively accepted in terms of her physical, psychological, and role forms, a woman will play her image well in a society. This can be seen from the role of Jeng Yah in a society known for his fame as a Kretek Girl.

\section{REFERENCES}

[1] Nurgiyantoro, Burhan. 2015. Teori Pengkajian Fiksi. Yogyakarta: Gadjah Mada Unniversity Press.

[2] Rokhmansyah, Alfian. 2014. Studi dan Pengkajian Sastra; Perkenalan Awal terhadap Ilmu Sastra. Yogyakarta: Graha Ilmu.Yogyakarta: Graha Ilmu.

[3] Ratna, K. Nyoman. 2008. Teori, Metode dan Teknik Penelitan Sastra. Yogyakarta: Pustaka Pelajar.

[4] Sugihastuti dan Suharto. 2016. Kritik Sastra Feminis: Teori dan Aplikasi. Yogyakarta: Pustaka Pelajar.

[5] Kumala, Ratih. 2019. Gadis Kretek. Jakarta: PT Gramedia Pustaka Utama.

[6] Arikunto, Suharsimi. 2013. Prosedur Penelitian, Suatu Pendekatan Praktik. Jakarta: PT Rineka Cipta. 